\title{
Evaluation of Oxidative Stress and Antioxidant Status in Beta Thalassemia Major Patients: A Single-Center Study
}

\author{
NAHLA A. MOHAMMED, Ph.D.* and HANAN F. ABD-EL RASOUL, M.D.** \\ The Departments of Pediatrics* and Clinical Pathology**, El Gala Teaching Hospital, \\ General Organization of Teaching Hospital
}

\begin{abstract}
Background: Regular blood transfusion in children with beta thalassemia major lead toperoxidative tissue injury secondary to iron overload, increased oxidative stress and disturbance of oxidant anti-oxidantstatus of patients.

Aim of Study: The present study aimed to assessoxidative stress, trace elements and oxidant-antioxidants status of beta thalassemia-major $(\beta-\mathrm{TM})$ patients on regular blood transfusion.

Patients and Methods: A case-control study included 35 beta thalassemic patients attending the pediatric Haematologyclinic of El-Galaa Teaching Hospital and 35 age sex healthy matched subjects as control group. Serumzinc ( $\mathrm{Zn})$, copper $(\mathrm{Cu})$, magnesium $(\mathrm{Mg})$, serum Malondialdehyde (MDA), Superoxide Dismutase (SOD), serum catalase (CAT), Total Antioxidant Capacity (TAC) were performed for both patients and control.

Results: Meanserum iron, ferritin, Alanine Transaminase (ALT), Aspartate Transaminase (AST) and total bilirubin levels were significantly higher in the $\beta$-TM group while mean hemoglobin, hematocritand total iron binding capacity were lower in the $\beta$-TM group. A significant increase in the levels of MDA, SOD whereas significant decrease in the levels of serum $\mathrm{Zn}, \mathrm{Mg}$. TAC and CAT was observed in the $\beta$-TM group. No significant difference in serum $\mathrm{Cu}$ between patients and control. Serum ferritin was found to have positive correlation with patients' age, weight, height, ALT, AST and total bilirubin, MDA, serum iron while significant negative correlation with total iron binding capacity, serum $\mathrm{Zn}$ and $\mathrm{Mg}$ levels whereas no significant correlation with serum $\mathrm{Cu}$, SOD, CAT, TAC.
\end{abstract}

Conclusion: Childrenwith beta thalassemia major suffering from oxidative stress, deficiency of some micronutrients and endogenous antioxidants. Selected trace elements and antioxidants supplementation require further studies for their evaluation.

Key Words: Beta-thalassemia major - Oxidative stress Trace elements - Antioxidants.

Correspondence to: Dr. Nahla A. Mohammed, The Department of Pediatrics, El Gala Teaching Hospital, General Organization of Teaching Hospital

\section{Introduction}

BETA-THALASSEMIA major considers one of most common single gene inherited hemoglobinopathyresults from about 200 beta globin genes mutation [1]. The prevalence of $\beta$-thalassemia major about $3 \%$ in the world. In Egypt carrier rate of beta thalassemia-major ranged from 5.3 to $\geq 9 \%$ and new cases account for about 1000 per 1.5 million live births per year [2]. It characterized by the diminished or absent of $\beta$-globin chains synthesis that result in excessive $\alpha$ chains production and impaired hemoglobin tetramer formationleading to ineffective erythropoiesis [3]. The newly formed RBCs became more fragile with short life spanleading to sever anemia which require lifelong blood transfusions to maintain normal life [4].

Oxidative stress is defined as impaired balancebetween oxidants and antioxidants within the body due toexcessive peroxides and free radicals' production [5]. In patients with beta thalassemia major as recurrent blood transfusions are required due to severe anemia with increased iron absorption from gastrointestinal tract lead to secondary iron overload that exceed the ability of body to eliminated excess iron. Iron will be deposited as hemosiderin and ferritin in different body organs mainly myocardium, liver, spleenand endocrine organs [6]. The deposited iron lead to the formation of Reactive Oxygen Species (ROS) such assuperoxide anion $\left(\mathrm{O}_{2}-\right)$, hydroxyl radical $(\mathrm{OH})$, single oxygen and hydrogen peroxide $\left(\mathrm{H}_{2} \mathrm{O}_{2}\right)$, that responsible for development of oxidative stress in thalassemia major patients via Fenton reaction [7].

Use of iron chelation therapy and antioxidants can be helpful in the oxidative status regulation of patients with beta thalassemia major [8]. Trace elements and minerals play an essential role in 
maintaining normal functions of the body and should be present in suitable concentration to participating in many physiological processes [1]. Zinc one of the essential trace elements in humanacting as a cofactor for more than 300 enzymes, and has essential roles in human growth and development, plays important role in hemeproduction [9]. Copper participates inmany enzymatic reactions like reduction of superoxide dismutase, cytochrome oxidase, dopamine hydroxylase, and other oxidases [10]. Magnesium has an essential role for maintaining proper body functions as immune, cardiovascular and musculoskeletal systems [1].

\section{Patients and Methods}

The current study was a case-control crosssectional carried out on $35 \beta$-thalassemic patients diagnosed on the basis of clinical manifestation, hemoglobin electrophoresis and regular blood transfusion attended the Pediatric Outpatient Clinic at Galaa Teaching Hospital during period of November 2018 till April 2019. Patients with disease related complications such as thyroid dysfunction, diabetes mellitus, renal failure, infection or any other inherited diseases other than $\beta$-thalassemia major were excluded. A35 healthy childrenof matched age and sex were enrolled in the study as control group. None of the participants receiving vitamins or antioxidant supplements. Informed parental consent was obtained from all participants before enrollment in the study.

The study was approved by Ethics Committee of General Organization of Teaching Hospital and Institutes and conducted according to Helsinki declaration.

Detailed history taking including demographic data (age and sex). Family history including consanguinity, similar family condition. Type of iron chelation therapy, history of splenectomy. Thorough physical examination. Laboratory investigations including, Complete Blood Count (CBC), Alanine Transaminase (ALT), Aspartate Transaminase (AST) and total bilirubin, Total Iron Binding Capacity (TIBC), serum ferritin, serum iron, serum zinc $(\mathrm{Zn})$, copper $(\mathrm{Cu})$, magnesium $(\mathrm{Mg})$, serummalondialdehyde (MDA), superoxidedismutase (SOD), serum catalase (CAT), Total Antioxidant Capacity (TAC) were performed.

\section{Collection of samples:}

Blood samples collected from thalassemic patients just before receiving blood transfusion and controls group as following: $5 \mathrm{~mL}$ of blood collected by asepticvenipuncture into Ethylene Diaminet Etracetic Acid (EDTA) and plain tubes then left tobe clot for 30min at room temperature then centrifuged at $3,000 \mathrm{rpm}$ for $10 \mathrm{~min}$, the serum dispensed into clean tubes, then stored at $-20^{\circ} \mathrm{C}$ for analysis.

Determination of lipid peroxidation: Lipid peroxidation was assayed by measuring MDA level. It was assessed by measuring thiobarbituric reactive species using the method of Ruiz-Larrea et al., [11] in which the thiobarbituric acid reactive substances react with thiobarbituric acid to produce a red-colored complex having peak absorbance at $532 \mathrm{~nm}$.

Determination of anti-oxidant enzyme activity: Catalase and superoxide dismutase activity were determined spectrophotometrically using a commercially available kit (Biodiagnostics, Cairo, A.R.E).

Determination of trace elements: Measuring serum zinc, Iron, copper and magnesium levels using Flame Atomic Absorption Spectrometry.

\section{Statistical analysis:}

Data were collected, revised, coded and entered to the Statistical Package for Social Science (Released 2015. IBM SPSS Statistics for Windows, Version 23.0. Armonk, NY: IBM Corp.). The quantitative data were presented as mean, standard deviations and ranges while qualitative variables were presented as number and percentages. The comparison between groups regarding qualitative data was done by using Chi-square test. Also the comparison between two independent groups with quantitative data and parametric distribution was done by using Independent $t$-test and more than two independent groups was done by using One Way ANOVA test. Spearman correlation coefficients were used to assess the correlation between two quantitative parameters in the same group. Receiver Operating Characteristic curve (ROC) was used to assess the best cut off point with its sensitivity, specificity, Positive Predictive Value (PPV), Negative Predictive Value (NPV) and Area Under Curve (AUC). The confidence interval was set to $95 \%$ and the margin of error accepted was set to $5 \%$. So, the $p$-value was considered significant at the level of $<0.05$.

\section{Results}

Thirty-five patients were included in this study; $20(57.1 \%)$ males and $15(42.9 \%)$ females. Mean age was $9.65 \pm 3.91$ years (range $4-16$ years). Thirtyfive healthy controls were included with age 
ranged from 4 to 16.3 years; mean $8.25 \pm 3.87$. $\beta$ thalassemic patients had significantly lower weight, height and body mass index as compared to controls ( $p$-value $0.01,0.04$ and 0.000 respectively). Thirteen patients $(37.1 \%)$ had history of positive consanguinity and nine $(25.7 \%)$ had similar conditions in the family. Twenty-five (71.4\%) patients received chelation: 7 (20.0\%) received deferoxamine, 14 $(40.0 \%)$ deferiprone and $4(11.4 \%)$ received both. sixteen patients $(45.7 \%)$ had been splenectomizedas shown in (Table 1).

There was significant decrease in mean hemoglobin concentration $(p=0.000)$, mean hematocrit $(p=0.000)$ and significant increase of serum ferritin $(p=0.000)$, total iron binding capacity $(p=0.000)$, $\operatorname{AST}(p=0.000)$, ALT $(p=0.004)$ and total bilirubin $(p=0.000)$ in $\beta$-thalassemic patients as shown in (Table 2), Fig. (1).

There was significant decrease in the levels of serum of $\mathrm{Zn}, \mathrm{Mg}$, serum catalase and TAC ( $p=$ 0.000 ), while means value of Iron, MDA and SOD significantly elevated in patients than control $(p=0.000)$. No significant differences in the mean levels of $\mathrm{Cu}$ ( $p=0.651)$ between patients and control as shown in (Table 3), Fig. (2).

Table (4) shows correlation between serum ferritin, clinical, and laboratory data of $\beta$-thalassemic patients, there were significantly positive correlation between serum ferritin levels and age, weight, height $(r=0.875,0.785$ and $0.829, p$-value $=$ 0.000 respectively) also ALT, AST and total bilirubin $(r=0.344,0.417$ and $0.641, p$-value $=0.043$, 0.013 , and 0.000 respectively) and significant negative correlation with total iron binding capacity ( $r=-0.489, p=0.003$ ), while no significant correlation with body mass index, hemoglobin, hematocrit, platelet and total leukocytic counts in thalassemia patients.

There was significantly positive correlation were detected between serum ferritin levels, MDA, serum iron ( $r=0.513$ and $0.335, p$-value $=$ 0.002 and 0.049 respectively) and significant negative correlation with serum $\mathrm{Zn}$ and $\mathrm{Mg}$ levels $(r=-0.600$ and $-0.382, p$-value $=0.000$ and 0.023 respectively), but no significant correlation with serum $\mathrm{Cu}, \mathrm{SOD}, \mathrm{CAT}, \mathrm{TAC}$ in thalassemic patients (Table 5), Fig. (3).
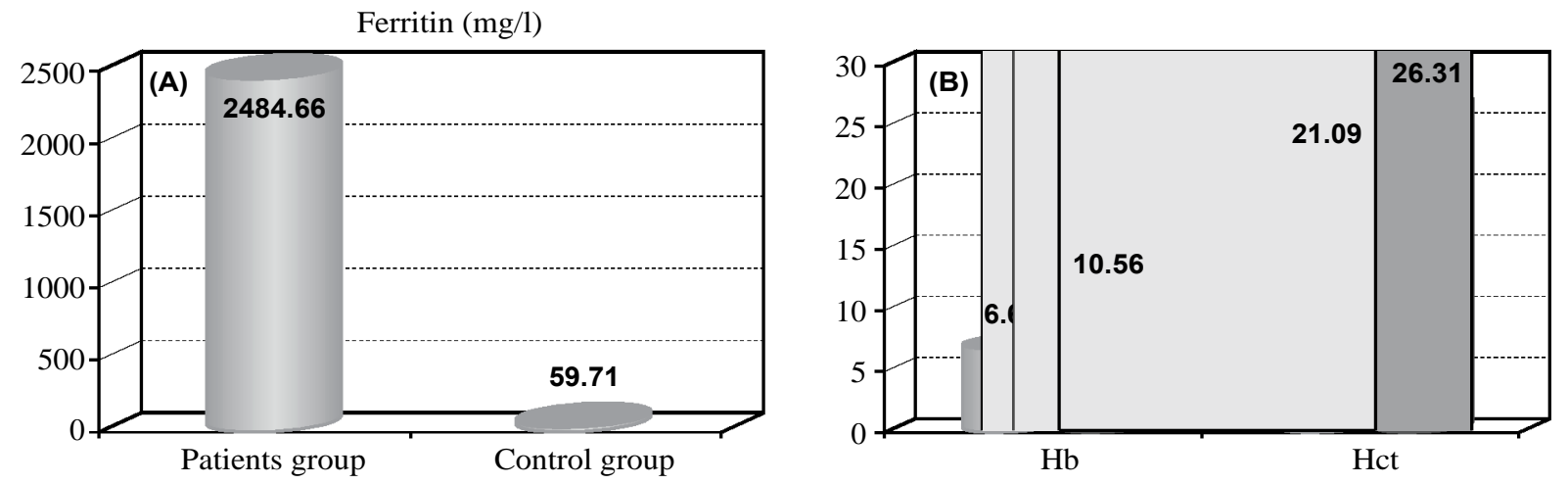

$\operatorname{TIBC}(\mathrm{mg} / \mathrm{dl})$
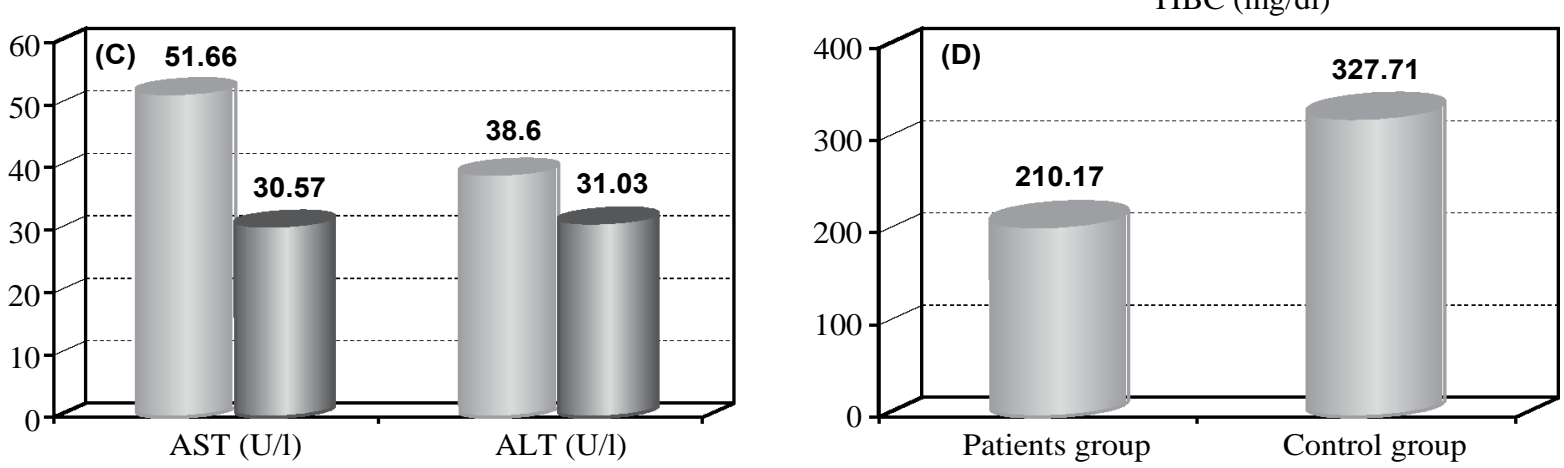

Patients group

Control group

Fig. (1): Comparison of hematological and biochemical investigations between patients and controls, (A) Ferritin, (B) Hemoglobin and hematocrit, (C) Aspartate transaminase and alanine transaminase, (D) Total iron binding capacity. 


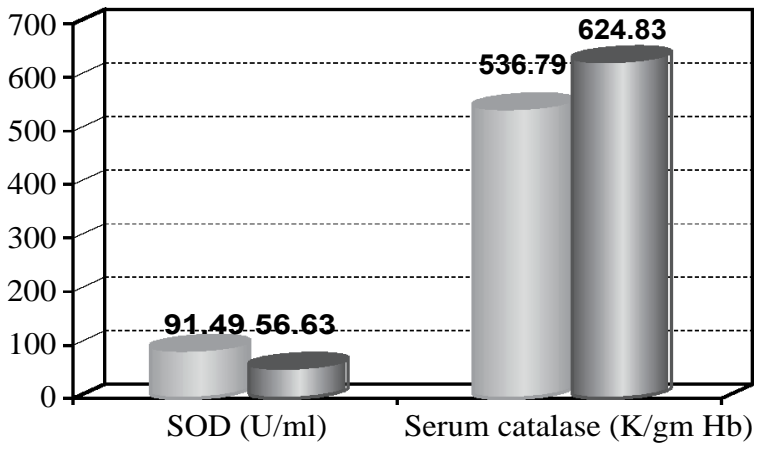

Patients group 1 Control group

Copper $(\mathrm{mg} / \mathrm{dl})$

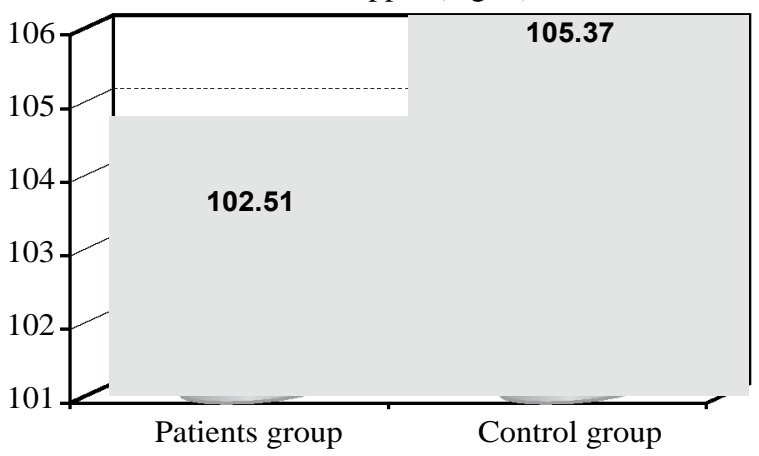

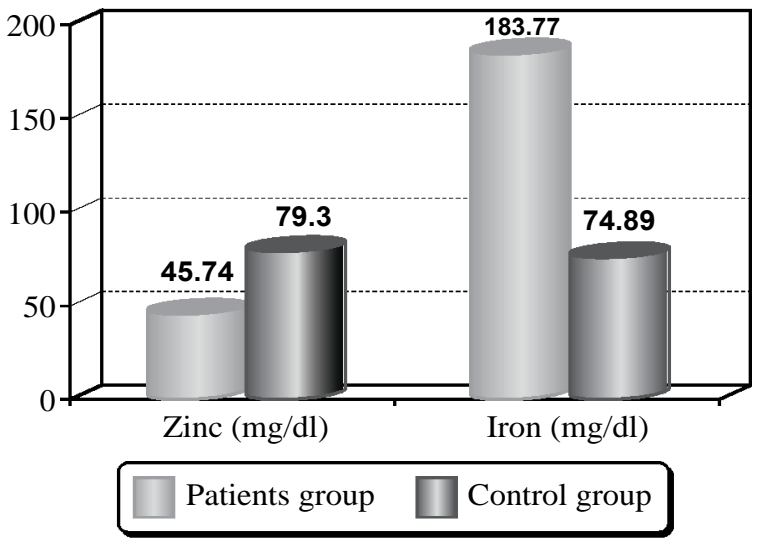

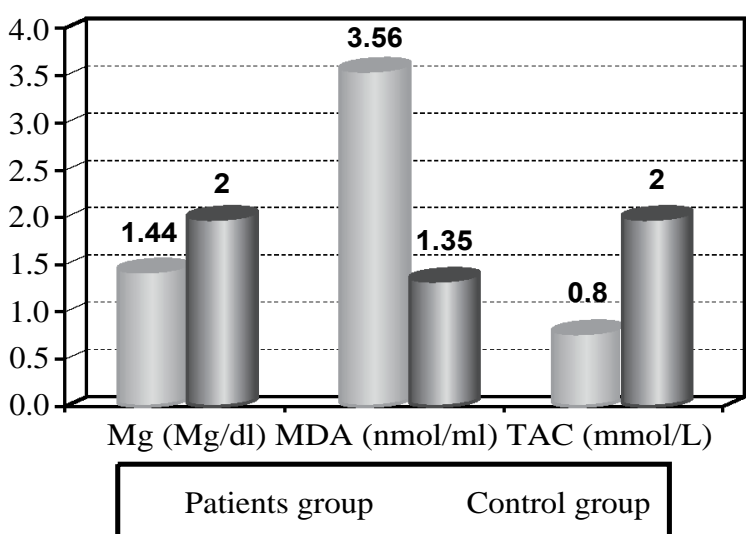

Fig. (2): Comparison of serum trace elements, antioxidant enzymes, malondialdehyde and total antioxidant capacity between patients and control, (A) Superoxide dismutase and catalase, (B) Zinc and iron, (C) Copper, (D) Magnesium, malondialdehyde and total antioxidant capacity.
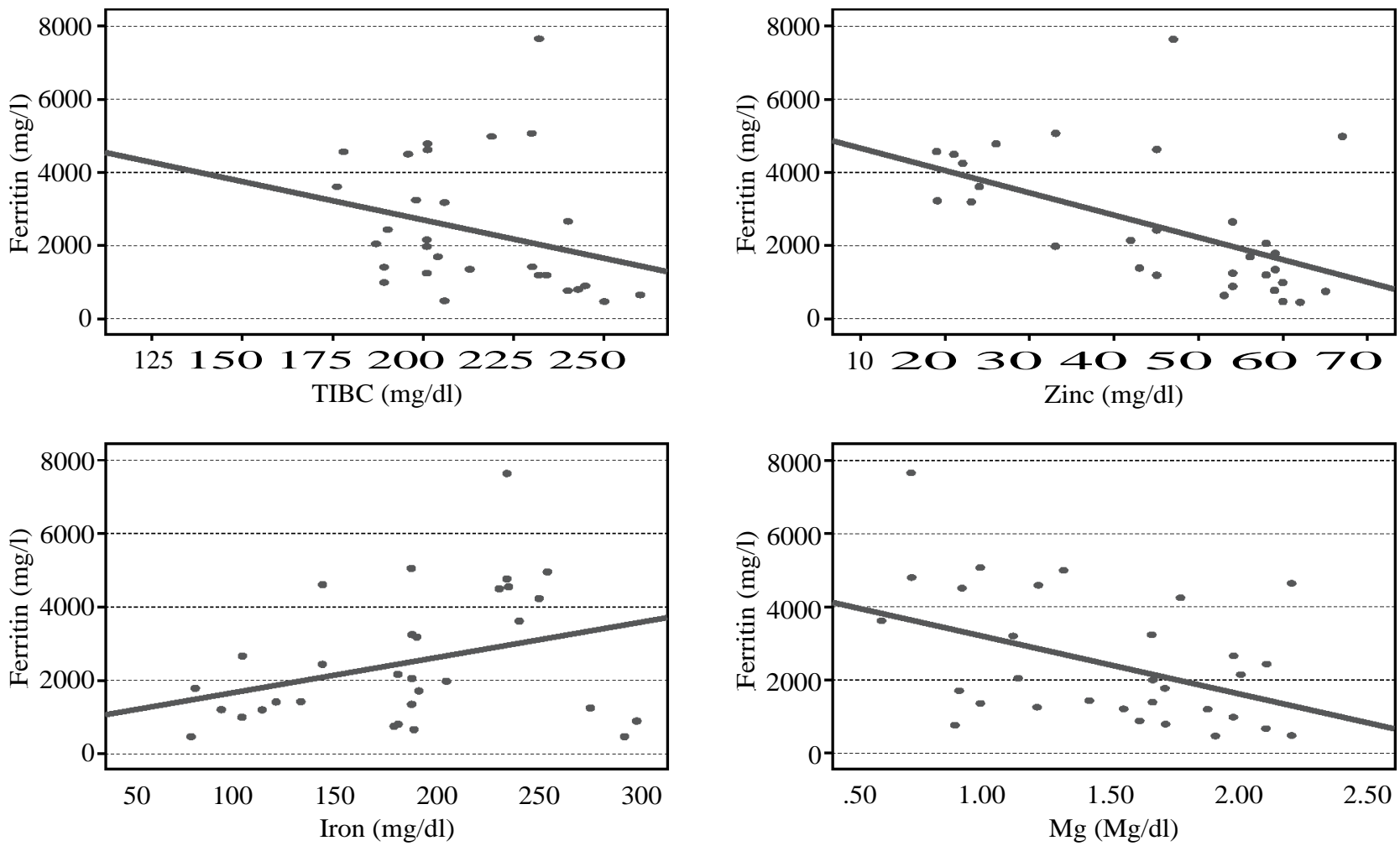

Fig. (3): Correlation of serum ferritin and TIBC (A), Zinc (B), Iron (C), Magnesium (D). 


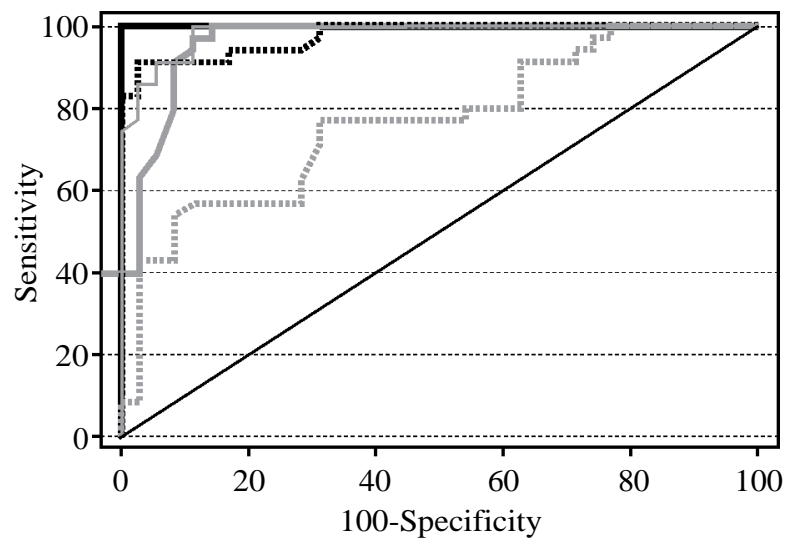

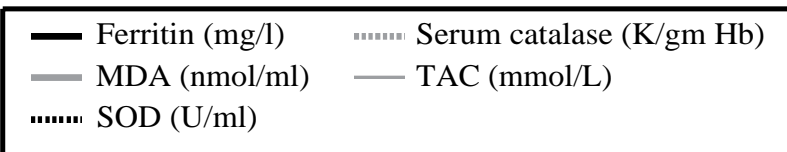

Fig. (4): Receiver Operating Characteristic curve (ROC) for the studied parameters as diagnostic markers for thalassemia major.

Table (1): Demographic and clinical data of the $\beta$ thalassemic patients and controls.

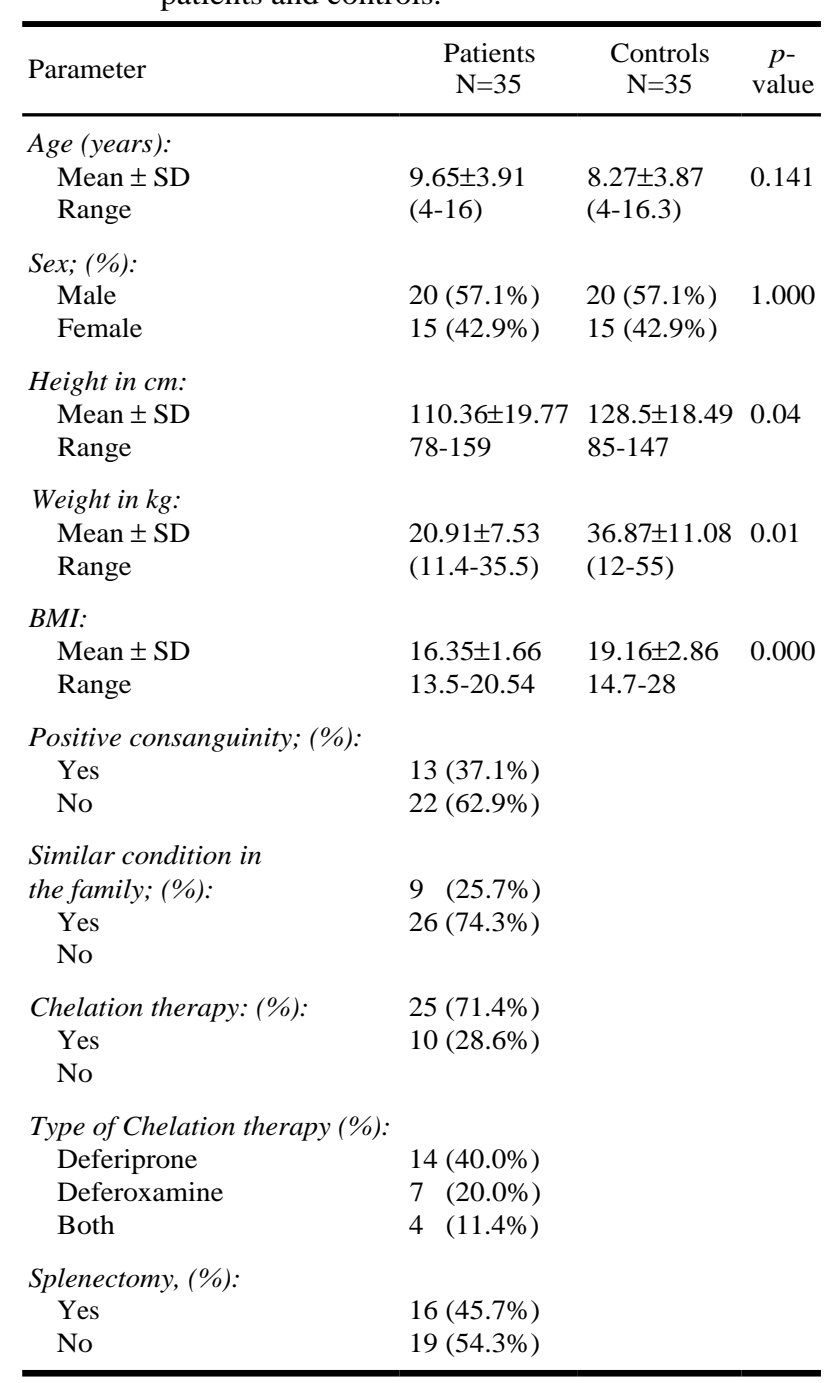

BMI: Body Mass Index.
Table (2): Laboratory data of the $\beta$ thalassemic patients and controls.

\begin{tabular}{|c|c|c|c|}
\hline Parameter & Patients & Controls & $p$-value \\
\hline \multicolumn{4}{|l|}{$H b:$} \\
\hline Mean $\pm \mathrm{SD}$ & $6.69 \pm 0.9$ & $10.56 \pm 1.53$ & 0.000 \\
\hline Range & $5.1-8.3$ & $7.5-13$ & \\
\hline \multicolumn{4}{|l|}{ Hct: } \\
\hline Mean \pm SD & $21.09 \pm 3$ & $26.31 \pm 2.91$ & 0.000 \\
\hline Range & $17-26$ & $19-32$ & \\
\hline \multicolumn{4}{|l|}{ Plt: } \\
\hline Mean \pm SD & $288.26 \pm 97.98$ & $286.06 \pm 132.93$ & 0.937 \\
\hline Range & $156-516$ & $145-654$ & \\
\hline \multicolumn{4}{|l|}{$T L C:$} \\
\hline Mean \pm SD & $8.39 \pm 2.05$ & $8.05 \pm 2.27$ & 0.510 \\
\hline Range & $5.5-12$ & 4-12 & \\
\hline \multicolumn{4}{|l|}{ Ferritin $(\mu g / l)$ : } \\
\hline Mean \pm SD & $2484.66 \pm 1706.13$ & $59.71 \pm 25.47$ & 0.000 \\
\hline Range & $465-7654$ & $18-132$ & \\
\hline \multicolumn{4}{|l|}{$T I B C(\mu g / d l):$} \\
\hline Mean \pm SD & $210.17 \pm 27.66$ & $327.71 \pm 59.43$ & 0.000 \\
\hline Range & $125-260$ & $241-452$ & \\
\hline \multicolumn{4}{|l|}{$A S T(U / l):$} \\
\hline Mean \pm SD & $51.66 \pm 17.81$ & $30.57 \pm 7.96$ & 0.000 \\
\hline Range SD & $34-132$ & $16-45$ & \\
\hline \multicolumn{4}{|l|}{$A L T(U / l):$} \\
\hline Mean \pm SD & $38.6 \pm 12.49$ & $31.03 \pm 8$ & 0.004 \\
\hline Range & $23-87$ & $17-45$ & \\
\hline \multicolumn{4}{|c|}{ Total bilirubin $(\mu \mathrm{mol} / \mathrm{l})$ : } \\
\hline Mean \pm SD & $2.36 \pm 0.63$ & $1.4 \pm 0.33$ & 0.000 \\
\hline Range SD & $1.1-3.4$ & $0.88-2.1$ & \\
\hline
\end{tabular}

$\mathrm{Hb}$ : Hemoglobin.

Hct : Hematocrit.

Plt : Platelet.

TLC : Total Leukocytic Count.

TIBC : Total Iron Binding Capacity.

AST : Aspartate Transaminase.

ALT : Alanine Transaminase.

The previous ROC curve shows that the best cut off point for ferritin level to detect thalassemia major was found $>132(\mathrm{mg} / \mathrm{l})$ with sensitivity of $100 \%$, specificity of $100 \%$ and Area Under Curve (AUC) of $100 \%$. Also the best cut off point for MDA level to detect thalassemia major was found $>1.8(\mathrm{nmol} / \mathrm{ml})$ with sensitivity of $100 \%$, specificity of $85.71 \%$ and Area Under Curve (AUC) of $96.3 \%$. While SOD best cut off point was found $>73(\mathrm{U} / \mathrm{ml})$ with sensitivity of $91.43 \%$, specificity of $97.14 \%$ and AUC of $97.5 \%$. Serum catalase level $(\mathrm{k} / \mathrm{gmHb})$ showed sensitivity of $54.29 \%$ and specificity of $91.43 \%$ at the cutoff point of $\leq 517$ and lastly TAC level showed sensitivity of $100 \%$, specificity of $88.57 \%$ and AUC of $98.4 \%$ at the cut off $\leq 1.2(\mathrm{mmol} / \mathrm{L})$. 
Table (3): Comparison of serum trace elements, antioxidant enzymes, malondialdehyde and total antioxidant capacity between $\beta$ thalassemic patients and controls.

\begin{tabular}{|c|c|c|c|}
\hline Parameter & Patients & Controls & $p$-value \\
\hline \multicolumn{4}{|l|}{ MDA (nmol/ml): } \\
\hline Mean \pm SD & $3.56 \pm 0.84$ & $1.35 \pm 0.72$ & \multirow[t]{2}{*}{0.000} \\
\hline Range & $2.2-5.2$ & $0.33-3.4$ & \\
\hline \multicolumn{4}{|l|}{$\operatorname{Zinc}(\mu g / d l):$} \\
\hline Mean \pm SD & $45.74 \pm 15.58$ & $79.3 \pm 17.44$ & \multirow[t]{2}{*}{0.000} \\
\hline Range & $19-67$ & $56-124$ & \\
\hline \multicolumn{4}{|l|}{ Copper $(\mu g / d l)$ : } \\
\hline Mean \pm SD & $102.51 \pm 30.86$ & $105.37 \pm 20.71$ & \multirow[t]{2}{*}{0.651} \\
\hline Range & $64-190$ & $76-152$ & \\
\hline \multicolumn{4}{|l|}{ Iron $(m g / d l)$ : } \\
\hline Mean \pm SD & $183.77 \pm 60.9$ & $74.89 \pm 38.11$ & \multirow[t]{2}{*}{0.000} \\
\hline Range & $78-298$ & $22-174$ & \\
\hline \multicolumn{4}{|l|}{$M g(\mu g / d l):$} \\
\hline Mean \pm SD & $1.44 \pm 0.49$ & $2 \pm 0.78$ & \multirow[t]{2}{*}{0.000} \\
\hline Range & $0.58-2.2$ & $0.56-3.4$ & \\
\hline \multicolumn{4}{|l|}{ SOD $(\mathrm{U} / \mathrm{ml}):$} \\
\hline Mean \pm SD & $91.49 \pm 17.34$ & $56.63 \pm 12.5$ & \multirow[t]{2}{*}{0.000} \\
\hline Range & $64.9-164$ & $33-77$ & \\
\hline \multirow{2}{*}{\multicolumn{4}{|c|}{$\begin{array}{l}\text { Serum Catalase } \\
(\mathrm{K} / \mathrm{gmH} \mathrm{H}) \text { : }\end{array}$}} \\
\hline & & & \\
\hline Mean \pm SD & $536.79 \pm 89.51$ & $624.83 \pm 84.93$ & \multirow[t]{2}{*}{0.000} \\
\hline Range SD & $389.8-687.4$ & $406-865$ & \\
\hline \multicolumn{4}{|l|}{ TAC (mmol/L): } \\
\hline Mean \pm SD & $0.8 \pm 0.15$ & $2 \pm 0.61$ & \multirow[t]{2}{*}{0.000} \\
\hline Range & $0.53-1.2$ & $0.88-3.06$ & \\
\hline
\end{tabular}

MDA : Malondialdehyde.

Mg : Magnesium.

SOD : Superoxide Dismutase.

TAC : Total Antioxidant Capacity.

Table (4): Correlation of serum ferritin, clinical, and laboratory data of patients.

\begin{tabular}{llc}
\hline & \multicolumn{2}{c}{ Serum ferritin $(\mu \mathrm{g} / \mathrm{dl})$} \\
\cline { 2 - 3 } Variables & \multicolumn{1}{c}{$r$} & $p$-value \\
\hline Age & $0.875^{* *}$ & 0.000 \\
Weight & $0.785^{* *}$ & 0.000 \\
Height & $0.829^{* *}$ & 0.000 \\
BMI & 0.022 & 0.899 \\
Hb & -0.189 & 0.278 \\
Hct & 0.110 & 0.531 \\
Plt & 0.322 & 0.059 \\
TLC & 0.196 & 0.260 \\
TIBC (mg/dl) & $-0.489^{* *}$ & 0.003 \\
AST (U/l) & $0.417^{*}$ & 0.013 \\
ALT (U/l) & $0.344^{*}$ & 0.043 \\
Total billirubin (mmol/l) & $0.641^{* *}$ & 0.000 \\
\hline
\end{tabular}

BMI : Body Mass Index.

$\mathrm{Hb}$ : Hemoglobin.

Hct : Hematocrit.

Plt : Platelet.

TLC : Total Leukocytic Count.

TIBC : Total Iron Binding Capacity.

AST : Aspartate Transaminase.

ALT : Alanine Transaminase.
Table (5): Correlation of serum ferritin, malondialdehyde, serum trace elements, antioxidant enzymes and total antioxidant capacity of $\beta$ thalassemic patients.

\begin{tabular}{llc}
\hline & \multicolumn{2}{c}{ Serum ferritin $(\mu \mathrm{g} / \mathrm{dl})$} \\
\cline { 2 - 3 } Variables & \multicolumn{1}{c}{$r$} & $p$-value \\
\hline MDA $(\mathrm{nmol} / \mathrm{ml})$ & $0.513^{* *}$ & 0.002 \\
Zinc $(\mathrm{mg} / \mathrm{dl})$ & $-0.600^{* *}$ & 0.000 \\
Copper $(\mathrm{mg} / \mathrm{dl})$ & 0.037 & 0.834 \\
Iron $(\mathrm{mg} / \mathrm{dl})$ & $0.335^{*}$ & 0.049 \\
Mg $(\mathrm{Mg} / \mathrm{dl})$ & $-0.382^{*}$ & 0.023 \\
SOD $(\mathrm{U} / \mathrm{ml})$ & -0.239 & 0.167 \\
Serum catalase $(\mathrm{K} / \mathrm{gmHb})$ & -0.229 & 0.186 \\
TAC $(\mathrm{mmol} / \mathrm{L})$ & -0.239 & 0.167 \\
\hline
\end{tabular}

\section{Discussion}

Oxidative stress is an important feature of beta thalassemia-major and plays a significant role in the pathophysiology of the disease [12]. The oxidative stress resulting from impairment of the oxidant and antioxidant balance via increasing levels of ROS or decreasing antioxidant defenses [13]. The current study conducted to evaluateoxidative stress, trace elements and oxidant-antioxidants status of beta thalassemia-major patients on regular blood transfusion.

Our study shows significant increased serum level of iron, ferritinand significant decrease in TIBC, that in agree with study done by Ghone et al., [8]. Regular blood transfusion as conventional therapy forbeta thalassemia-major to maintain hemoglobin levels near normal, also hemoglobin instability and increased absorption of iron from the gastrointestinal tract consider major causes of iron overload in $\beta$-thalassemia. In these patients, higher iron has a catalytic role in producing powerful ROS and free radicals, that result in oxidative damage [14].

The present study shows significant increased liver enzymes, ALT and AST also there was significant increased total bilirubin that in concords with several studies by Attia et al., [7], Qariet al., [15], Abed Mahdy et al., [16] and Nafadya et al., [17] that may be due to hepatocellular injury secondary to iron deposition in liver.

In the current study there was significant increase serum level of MDAin studied group as compared to control. MDA is good indicator of oxidative damage, also MDA is the end product of polyunsaturated fatty acid oxygenation which commonly used as marker for the lipid peroxidation levels and for the presence of oxidative stress, that may result in antioxidantsdepletion. Our results were supported by Livrea et al., [18] and Attia et 
al., [7] who observed elevated levels of MDA in beta thalassemia major patients.

Our study shows significant decrease in mean serum zinc levels as compare thalassemic group and control that may explain by inadequate dietary intake of zinc, increased urinary excretion, chronic hemolysis, usage of iron chelation therapy that has high affinity for zinc as well as iron. Similar to our finding, the study of Tabatabei et al., [19] that observe about $84.8 \%$ of patients had deficiency of zinc and alsoother studies done by Yazdideha and Faranosh [20] and Sherief et al., [21]. On the other hand, the studies done by El Missiry et al., [9] andFahmy et al., [22] reported normal zinc levels in beta thalassemia major patients, while Mehdizadeh et al., [23] observed high serum zinc levels in patients.

Our study shows no significant difference in mean serum copper levels between thalassemic patients and control. Our finding in concords to studies done by $[\mathbf{1 0 , 2 2}]$ that observe normal serum copper levels in about $77 \%$ and $50 \%$ of patients respectively. While elevated serum copper level in beta thalassemia major patients observed by studies done by Al-Samarrai et al., [24] and Zekavat et al., [25] but copper deficiency reported by study done [21]. Variation in serum copper levels can be explained by many factors as amount of copper intake, intestinal absorption of copper, kidney function, iron overload, zinc to copper ratioand intake of iron chelation therapy.

Significantly decreased levels of $\mathrm{Mg}$ were observed as comparing patients and control $(p=0.000)$. Our finding in concords to study done by Abbasciano et al., [26]. While studies by [22,27] observed normal serum magnesium levels of thalassemic patients where as higher levels were observed by [24].

Our study shows significant elevated serum SOD levels in children with $\beta$-TM. Our finding is in agreement with several studies by $[\mathbf{7 , 1 5 , 1 6 , 2 8 ]}$. In contrast to our result studies by Dhawan et al., [29] Patne et al., [30], Nafadya et al., [17] that observed significant decrease in erythrocyte activity of SOD in children with $\beta$-TM as compared with control, while another study by Simseket al., [31] reported that no significance difference in SOD levels between patients and control. Increased SOD activity in beta thalassemic patients which impotent antioxidants enzyme protects erythrocyte from harmful effects of excess ROS created by iron overload may be due to regular blood transfusion that supply patients with normal RBCs and compensatory mechanism of body against oxidative stress.

There was significant down regulation of catalase levels in $\beta$-thalassemic patients as compared with control, our finding in concords with many studies by [32-34] that observed decrease catalase enzyme which responsible for hydrogen peroxide detoxification in the cells due to increase damounts of hydrogen peroxide which produce direct toxic effects on catalase, while studies by $[15,35,36]$ that observe significant increaseof catalase activity in beta thalassemia major patients which may be due to increased oxidative stress.

There was significant decrease in TAC levels as comparing $\beta$-thalassemic patients and control. Our finding is in agreement with study [8] which may be due to its consumption for neutralization the action of excess ROS and oxidative stress.

In the present study, there was a significant positive correlation between ferritin level, ALT, AST and total bilirubin that may be due to liver injury secondary to iron over load, our finding in agreement to several studies by $[\mathbf{8 , 1 7 ]}$, also there was significant negative correlation between ferritin level and serum zinc and magnesium but no significant correlation with copper, our results disagree to study by [21] that reported significant negative correlation between ferritin level and magnesium but no significant correlation with serum zinc and copper.

\section{Conclusion:}

Beta-thalassemic patients had an increased oxidative stress mainly occurred as result of peroxidative injury secondary to iron overload. Excess free radicals' formation by iron overload, alteration of serum minerals and trace element and depletion of anti-oxidants play essential role in beta thalassemia pathogenesis. Antioxidant and trace elements supplementation may play a role in improving antioxidant capacity of the plasma and decreasing the oxidant levels which may improve the clinical course of Beta-thalassemia major and reduce disease related complications. Further studies with larger sample size and longer duration of follow-up will be required.

\section{References}

1- SHAZIA Q., MOHAMMAD Z.H., RAHMAN T. and SHEKHAR H.U.: Correlation ofoxidative stress with serum trace element levels and antioxidantenzyme status in beta thalassemia major patients: A review of theliterature. Anemia, 2012: 7, 2012. 
2- EL-BESHLAWY A., KADDAH N., MOUSTAFA A., MOUKTAR G. and YOUSSRY I.: Screeningfor? Thalassaemia carriers in Egypt: Significance of the osmotic fragilitytest. East Mediterr. Health J., 13: 780-6, 2007.

3- KARIMI M., COHAN N., De SANCTIS V., et al.: Guidelines for diagnosis and management of beta-thalassemia intermedia. Pediatr. Hematol. Oncol., 31: 583-96, 2014.

4- NAEEM S., FOUZIA B., RUBAB N., GHULAM M.S., HAFIZ A. and ABDUL Q.: Role of ironchelation therapy for beta-thalassemia major: A review. J. Appl. Environ. Biol. Sci., 4: 17-25, 2014.

5- KUNWAR A. and PRIYADARSINI K.: Free radicals, oxidative stress and importance of antioxidants in human health J. Med. Allied. Sci., 1 (2): 53-60, 2011.

6- PAVLOVA L.E., SAVOV V.M., PETKOV H.G. and CHAROVA I.P.: "Oxidative stress in patients with betathalassemia major," Prilozi, 28 (1): 145-54, 2007.

7- ATTIA M., SAYED A., IBRAHIMF. and MEAAD H.: Effect of Antioxidant Vitamins of the Oxidant/AntiOxidant Status and Liver Functionin Homozygous Beta Thalassemia, Roman J. Biophes, 21 (2): 93-106, 2011.

8- GHONE R.A., KUMBAR K.M., SURYAKAR A.N., KATKAM R.V. and JOSHI N.G.: "Oxidative stress and disturbance in antioxidantbalance in beta thalassemia major," Indian Journal of Clinical Biochemistry, 23 (4): 337-40, 2008.

9- EL MISSIRY M., HAMED HUSSEIN M., KHALID S., YAQUB N., KHAN S., ITRAT F., et al.: Assessment of serum zinc levels of patients with thalassemia compared totheir siblings. Anemia, 2014: 125452, 2014.

10- MAHYAR A., AYAZI P., PAHLEVAN A.A., MOJABI H., SEHHAT M.R. and JAVADI A.: Zinc andcopper status in children with Beta-thalassemia major. Iran J. Pediatr., 20: 297-302, 2010.

11- RUIZ-LARREA M.B., LEAL A.M., LIZA M., LACORT M. and De GROOT H.: Antioxidant effects of estradiol and 2-hydroxyestradiol on iron-induced lipid peroxidation of rat liver microsomes. Steroids, 59: 383-8, 1994.

12- FIBACH E. and RACHMILEWITZ E.A.: Pathophysiology and treatment of patients with beta-thalassemia-an update. F1000 Res., 6: 2156, 2017.

13- CHIRICO E.N. and PIALOUX V.: Role of oxidative stress in the pathogenesis of sickle cell disease. IUBMB Life, 64: 72-8, 2012

14- ANUPAMA B., PRASHANT J., SANJAY B. and VINOD R.: Effect of Blood Transfusions on Oxidant/Antioxidants Balance in BTM Patients, Journal of Clinical and Diagnostic Research, 12 (5): BC14-BC18, 2018.

15- QAISER S., HOQUE M.Z., IQBAL M. and MUDIN D.K.D.: Evaluation of Antioxidant Status in Beta-Thalassemia Major Patients in Sabah, Malaysian Borneo. Biores. Comm., 1 (1): 45-7, 2015. QARI M.H., WALI Y., ALBAGSHI M.H., ALSHAHRANI M., ALZAHRANI A., ALHIJJI I.A., et al.: Regional consensus opinion for the management of Beta thalassemia major in the Arabian Gulf area Qari et al. Orphanet. J. Rare Dis., 8: 143, 2013.

16- ABED MAHDY E.: Relationship between oxidative stress and antioxidantstatus in beta thalassemia major patients.
Acta Chim. Pharm. Indica, 4: 137-45. ISSN 2277-288X, 2014.

17- NAFADY A., ALI S.S., EL MASRY H.M., BASEER K.A., QUBAISY H.M., MAHMOUD S.G. and NAFADYHEGO H.A.: Oxidative stress in pediatric patients with $\beta$ thalassemia major. The Egyptian Journal of Haematology, 42 (3): 123, 2017.

18- LIVREA M.A., TESORIERE L., PINTAUDI A.M., CALABRESE A., MAGGIO A., FREISLEBEN H.J., et al.: Oxidative stress and antioxidant status in beta-thalassemia major: Iron overload and depletion of lipid soluble antioxidants. Blood, 88 (9): 3608-14, 1996.

19- TABATABEI M., KAMKAR M. and HABIBZADEH M.R.: Metabolic and endocrine complications in $\beta$ thalassemia major; a multicenter study in Tehran. Boshehr. Med. J., 5: 72-3, 2003.

20- YAZDIDEHA M.S. and FARANOSH M.: Evaluation of serum zinc in children affected with beta thalassemic patients. Res. Med., 24: 7-9, 2004.

21- SHERIEF L.M., ABD EL-SALAM S.M., KAMAL N.M., et al.: Nutritional biomarkers in children and adolescents with beta-thalassemia major: An Egyptian center experience. Biomed Res. Int., 2014: 261761, 2014.

22- FAHMY M., SALAMA H. and NESREEN A.: Mohammed. Copper, zinc, and magnesium status among patients with thalassemia, Egyptian Journal of Haematology, 44: 981047, 2019.

23- MEHDIZADEH M., ZAMANI G. and TABATABAEE S.: Zinc status in patients with major beta-thalassemia. Pediatr. Hematol. Oncol., 25: 49-54, 2008.

24- AL-SAMARRAI A.H., ADAAY M.H. and AL-TIKRITI K.A.: Evaluation of some essentialelement levels in thalassemia major patients in Mosul district. Iraq Saudi Med. J., 29: 94-7, 2008.

25- ZEKAVAT O.R., BAHMANJAHROMI A., HAGHPANAH S., EBRAHIMI S. and COHAN N.: The zinc and copper levels in thalassemia major patients, receiving iron chelation therapy. Journal of Pediatric Hematology/Oncology, 40 (3): 178-81, 2018.

26- ABBASCIANO V., BADER G., GRAZIANO L., MAZZOTTA D., VECCHIATI G., GUGLIELMINI C., et al.: Serum and erythrocyte levels of magnesium in microcytosis: Comparison between heterozygous beta-thalassemia and sideropenic anemia. Haematologica, 76: 339-41, 1991.

27- ARCASOY A. and CAVDAR A.O.: Changes of trace minerals (serum iron, zinc, copper and magnesium) in thalassemia. Acta Haematol., 53: 341-6, 1975.

28- DEL BO C., PORRINI M., CAMPOLO J., PAROLINI M., LANTI C., KLIMIS-ZACAS D. and RISO PA.: Single blueberry (Vacciniumcorymbosum) portion does not affect markers of antioxidant defence and oxidative stress in healthy volunteers following cigarette smoking. Mutagenesis, 31: 215-24, 2016.

29- DHAWAN V., KUMAR K.H.R., MARWAHA R.K., NARAVAN S. and KAMGAR M.: Antioxidantstatus in children with homozygous thalassemia. Indian Pediatr., 42: 1141-5, 2005. 
30- PATNE A.B., HISALKAR P.J., GAIKWAD S.B. and PATI S.V.: Alterations in antioxidant enzyme status with lipid peroxidation in thalassemia major patients. Int. J. Pharm. Life Sci., 3: 2003-6, 2012.

31- SIMSEK F., ÖZTÜRK G., KEMAHL S., ERBAS D. and HASANOGLU A.: Oxidant andantioxidant status in beta thalassemia major patients. Ankara Üniversitesi Tip Fakültesi Mecmuası, 58: 34-8, 2005.

32- MAHDI E.: Relationship between oxidatve stress and antioxidant status in Beta Thalassemia major patients. Acta Chimica and Pharmaceutica Indica, 4 (3): 137-45, 2014.

33- CHOUDHARY M., VYAS R.K. and LAHOTI A.: Correlation of oxidative stress with serum antioxidant enzymes level in thalassemia in a tertiary level hospital of western
Rajasthan. International Journal of Biotechnology and Biochemistry, 13 (2): 155-65, 2017.

34- NAZAR A., SAYRAN S. and GALAWESH N.: The Studying of oxidative stress and some biochemical parameters in patients with B-Thalassemia Major in Kirkuk City. International Journal of Sciences: Basic and Applied Research (IJSBAR), 42 (2): 239-51, 2018.

35- BOUDRAHEM-ADDOUR N., IZEM-MEZIANE M., BOUGUERRA K., et al.: "Oxidative status and plasma lipid profile in $\beta$-thalassemia patients," Hemoglobin, 39 (1): $36-41,2015$.

36- LAZARTE S.S., MÓNACO M.E., JIMENEZ C.L., LEDESMA ACHEM M.E., TERÁN M.M. and ISSÉ B.A.: Erythrocyte catalase activity in more frequent microcytic hypochromic anemia: Beta-thalassemia trait and iron deficiency anemia. Advances in hematology, 1-7, 2015.

\section{تقييم حالة التأكسل ومضادات الآكسدة

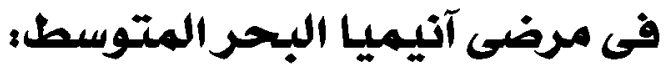

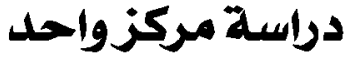

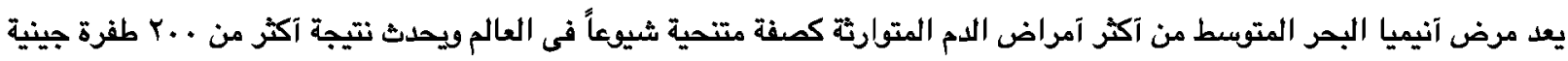

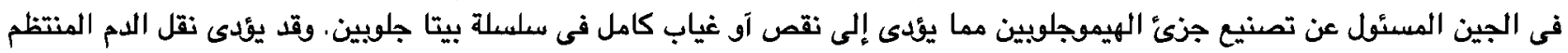

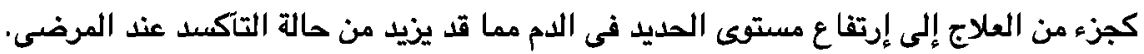

تهذف هذه الدراسة إلى تقييم ودراسة عوامل الآكسدة ومضادات الآكسدة وبعض المعادن الهامة عند المرضى المصابين بآنيميا البحر المتوسط الذين يعالجن بنقل الدم بإنتظام.

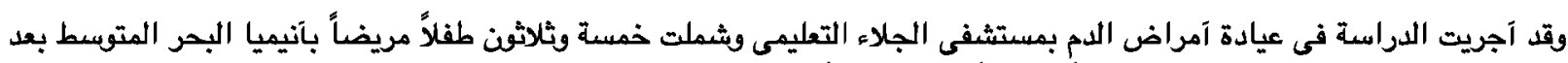

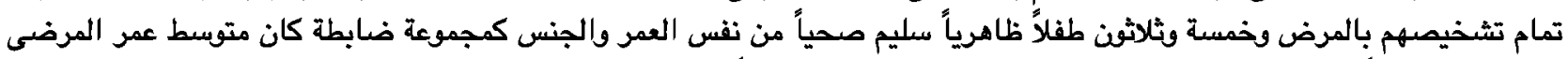

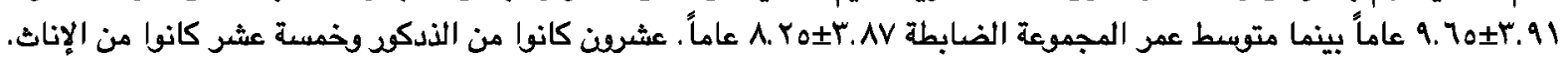

وخضعت جميع الحالات إلى الفحص الإكلينيكى، والتحقيقات المختبرية الرتينية، وتحديد نسبة مادة المالوندايلدهايد، نسبة مضادات

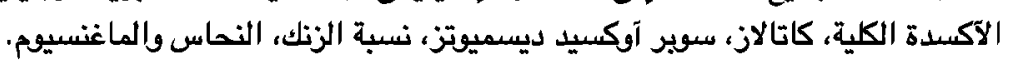

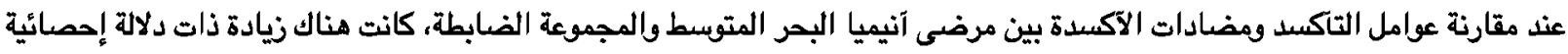

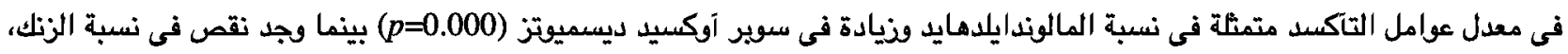

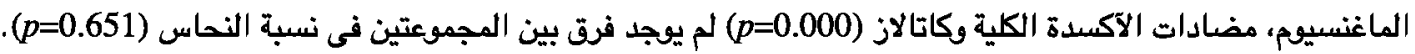

وجلت زيادة ذات دلالة إحصائية في نسبة الحديد والفرياتين ووظائف الكبد ونسبة الصفراء الكلية بينما كان هناك نقص فى نسبة الهوجلوبين

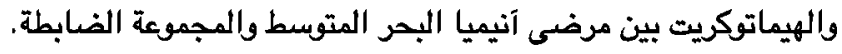

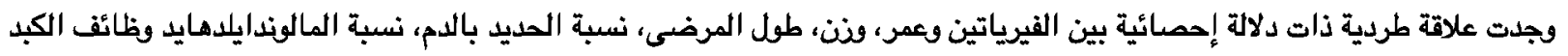

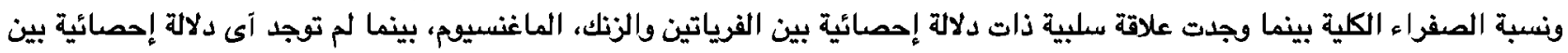

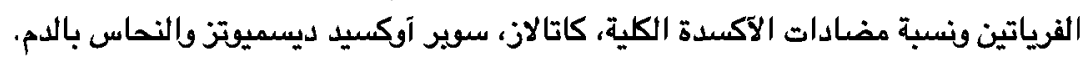

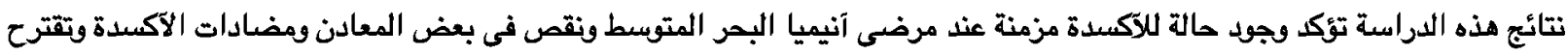

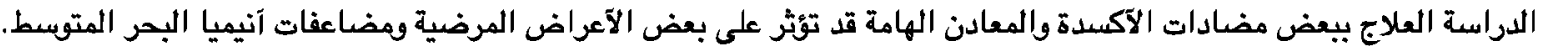

